\title{
PELATIHAN KEWIRAUSAHAAN BAGI MAHASISWA PROGRAM STUDI PENDIDIKAN PANCASILA DAN KEWARGANEGARAAN IKIP PGRI PONTIANAK
}

\author{
Hadi Rianto $^{1}$, Zuldafrial ${ }^{2}$, Sulha $^{3}$, Yuliananingsih ${ }^{4}$, Dada Suhaida ${ }^{5}$, \\ Hemafitria $^{6}$, Rohani $^{7}$, Syarif Firmansyah ${ }^{8}$, Fety Novianty ${ }^{9}$, Erna Octavia ${ }^{10}$, \\ Moad $^{11}$, M. Anwar Rubei ${ }^{12}$ \\ 1,2,3,4,5,6,7,8,9,10,11,12 Program Studi PPKN, Fakultas Ilmu Pendidikan dan Pengetahuan Sosial, \\ IKIP PGRI Pontianak, Jalan Ampera No. 88 Pontianak \\ 1e-mail: hdrianto@yahoo.com
}

\begin{abstract}
Abstrak
Kegiatan pelatihan ini bertujuan untuk (1) menumbuhkan dan meningkatkan kemampuan, minat mahasiswa untuk menekuni dunia wirausaha, (2) meningkatkan kreativitas berpikir mahasiswa dalam mengembangkan kemampuan wirausaha, (3) membuka wawasan tentang perkembangan dunia wirausaha di Kalimantan Barat, dan (4) memberikan motivasi kepada dosen dan mahasiswa untuk dapat berpartisipasi dalam mengembangkan dunia wirausaha di Kalimantan Barat. Selain itu, kegiatan ini diharapkan akan memberikan manfaat pada peningkatan kemampuan, minat, motivasi, inovasi, dan kreativitas mahasiswa untuk menekuni dunia wirausaha, meningkatnya kreativitas berpikir mahasiswa dalam mengembangkan kemampuan wirausaha, membuka wawasan tentang perkembangan dunia wirausaha di Kalimantan Barat, dan mendorong motivasi kepada dosen dan mahasiswa untuk dapat berpartisipasi dalam mengembangkan dunia wirausaha di Kalimantan Barat. Peserta kegiatan pelatihan kewirausahaan adalah mahasiswa Prodi PPKn di IKIP PGRI Pontianak terdiri dari 40 orang. Tempat kegiatan yaitu Balai Pertemuan Desa Sungai Baru Kecamatan Telok Keramat Kabupaten Sambas. Pengenalan terhadap dunia dan peluang usaha tentunya akan memungkinkan peningkatan motivasi individu bahwa upaya kewirausahaan akan memberikan hasil yang jauh lebih baik daripada hanya duduk menunggu peluang mejadi orang yang bekerja diperkantoran.
\end{abstract}

Kata kunci: pelatihan kewirausahaan, motivasi kewirausahaan

\begin{abstract}
The training activities carried out aim (1) to foster and enhance abilities, interests, students to pursue the world of entrepreneurship, (2) increase students' creativity in developing entrepreneurial abilities, (3) open up insights about the development of the entrepreneurial world in West Kalimantan, and (4) provide motivation to lecturers and students to be able to participate in developing the world entrepreneur in West Kalimantan. In addition, this activity is expected to benefit students 'ability, interest, motivation, innovation, and creativity to pursue entrepreneurship, increase students' thinking creativity in developing entrepreneurial abilities, open up insights on the development of entrepreneurship in West Kalimantan, and encourage motivation to lecturers and students to be able to participate in developing the world of entrepreneurship in West Kalimantan. Participants in the Entrepreneurship Training activity are PPKn Study Program students at IKIP PGRI Pontianak consisting of 40 people. The place of the activity was the meeting place of Sungai Baru Village, Telok Keramat District, Sambas Regency. The introduction of the world and business opportunities will certainly enable an increase in individual motivation that entrepreneurial efforts will yield far better results than just sitting waiting for opportunities to become people who work in offices.
\end{abstract}


Keywords: entrepreneurship training, entrepreneurship motivation

\section{PENDAHULUAN}

Kemandirian merupakan salah satu penentu kesanggupan setiap individu untuk memenuhi segala macam tuntutan dan kebutuhan hidupnya. Pada era globalisasi kini setiap generasi muda dituntut tidak hanya mandiri saja, namun lebih dari itu mereka harus mampu mengembangkan kemampuan berpikir kritisnya, yang lebih diarahkan pada pengembangan kemampuan berpikir kreatif sehingga hasil pemikiran yang disampaikan tidak hanya berguna untuk diri sendiri, akan tetapi juga bermanfaat untuk orang banyak. Sejalan dengan argumentasi ini, Chandler and Hanks, (1994) menyatakan bahwa ...an individual with more ventures and higher levels and varieties of resources tend to become more enthusiastic and ambitious and tend to grow faster in size when pursuing entrepreneurship compared to those with limited resources. Kemampuan berpikir kreatif cenderung ambisius dan antusias, dan ini akan menunjang aktivitas dan kreativitas generasi muda, karena kreativitas dan inovasi generasi muda adalah kunci untuk memulai wirausaha, karena dengan keduanya pula, wirausahawan akan tetap bertahan dalam berbagai perubahan iklim bisnis dan industri.

Usia muda tidak berpengalaman itu hal wajar, usia tua berpengalaman itu juga merupakan hal yang wajar, tapi pemuda yang memiliki kreatifitas tinggi akan menjadi sesuatu yang luar biasa. Ungkapan tersebut seharusnya dapat menjadi inspirasi bagi para generasi muda masa kini. Namun kini yang sering ditemui adalah rendahnya minat lulusan perguruan tinggi terhadap karir wirausaha, rendahnya minat tersebut memang cukup beralasan karena para lulusan tidak kurang dan bahkan sama sekali tidak mendapatkan bekal yang memadai ketika masih menempuh pendidikan di bangku kuliah. Zain et.al., (2010) menegaskan bahwa"... that academics need to play a significant role in encouraging more students to become entrepreneurs by providing more awareness on the benefits of becoming entrepreneurs and in turn, contributing to the growth of the country's economies and global competitiveness". Oleh karena itu tanggung jawab penyusunan kurikulum, metode pembelajaran dan pengajaran tidak di desain yang 
mengarah pada implikasi kewirausahaan, tidak hanya sebatas pada pengertian dan pemahaman saja, di tambah lagi dengan berbagai penelitian menunjukkan bahwa pendidikan dan pelatihan mempengaruhi persepsi orang terhadap karir kewirausahaan.

Rendahnya minat berwirausaha di kalangan lulusan perguruan tinggi merupakan masalah yang menjadi perhatian bersama. Seharusnya mereka menyadari bahwa dunia kerja dan ketersediaan lapangan pekerjaan sudah tidak memungkinkan lagi untuk menyerap seluruh lulusan perguruan tinggi sehingga mereka mulai beralih untuk memilih karir menjadi wirausaha. Hal ini memang secara khusus menjadi tantangan bagi kalangan institusi pendidikan. Meskipun demikian berbagai hal sudah dilakukan oleh institusi pendidikan tinggi, mulai memperbaiki kurikulum yang disesuaikan dengan kebutuhan kewirausahaan, pengembangan metode pembelajaran dan pengajaran serta perbaikan yang mengarah pada pembentukan karakter wirausaha. Namun demikian hasilnya masih belum terlihat secara nyata. Para lulusan perguruan tinggi tampaknya masih enggan untuk langsung terjun sebagai wirausaha. Namun demikian, institusi pendidikan tinggi tetap perlu untuk berjuang dalam menumbuhkan minat berwirausaha di kalangan mahasiswa. Minat berwirausaha di Indonesia dapat diawali dari bangku kuliah dan harus segera ditingkatkan. Ada baiknya jika kurikulum dan metode pembelajaran/perkuliahan yang diberikan mampu menumbuhkan karakter seperti memiliki kebutuhan akan prestasi, mengkalkulasi pengambilan risiko, kreatif, berpikir secara bebas dan berinovasi sehingga setelah lulus kuliah tidak hanya mencari kerja tetapi justru mampu memulai dan menjalankan usaha, baik secara perorangan maupun bekerja sama dengan pihak lain.

Sejumlah faktor telah diprediksi dapat mempengaruhi minat seseorang untuk berkarir sebagai wirausaha, seperti keinginan untuk menjadi wirausaha, faktor kepribadian, keterampilan berwirausaha, serta ketersediaan sarana dan modal (Zain et.al., 2010). Disamping itu, terdapat faktor lain seperti demografi dan kontekstual seperti umur, jenis kelamin, pengalaman kerja dan ketidakpuasan kerja dalam memobilisasi perilaku kewirausahaan (Linan et.al, 2005; Wilson, et 
al., 2007; dalam Pihie, 2009). Menurut Law \& Hung (Soehadi, et.al, 2011), upaya memahami karakteristik wirausaha dengan menggunakan aspek kepribadian menghasilkan karakteristik wirausaha yang berani dan cenderung mengambil resiko, berorientasi mencapai hasil, komitmen, toleransi terhadap ketidakpastian dan mempunyai visi. Untuk dapat menumbuhkembangkan minat mahasiswa agar berkarir sebagai wirausaha maka dibutuhkan upaya untuk meningkatkan faktor kepribadian mereka. Faktor kepribadian meliputi kebutuhan akan berprestasi, bersahabat dengan ketidakpastian, dan keberanian mengambil resiko serta percaya diri. Faktor kepribadian tersebut dapat dipupuk dan ditingkatkan melalui pengembangan kemampuan, bakat, atau keterampilan setiap mahasiswa (soft skill) yang mereka miliki. Di samping itu, perbaikan kurikulum, metode pembelajaran dan pengajaran tetap perlu untuk dibenahi.

Identifikasi masalah yang dihadapi oleh lulusan Program studi PPKN IKIP PGRI Pontianak berdasarkan data yang diperoleh, masih rendahnya minat berwirausaha lulusan IKIP PGRI Pontianak, rendahnya muatan kurikulum tentang kewirausahaan, dan belum memadainya kegiatan-kegiatan mahasiswa yang berkaitan dengan dunia kewirausahaan.

Kerangka pemecahan masalah dalam kegiatan ini adalah dengan melakukan pelatihan dan bimbingan kepada mahasiswa untuk menumbuhkembangkan budaya wirausaha. Pemilihan kegiatan dalam bentuk pelatihan ini mempertimbangkan efisiensi efektivitasnya yakni berkaitan dengan masalah dana, waktu dan pemanfaatannya. Kegiatan ini cukup dilaksanakan dengan dana seperti yang diminta dalam proposal, dan pemanfaatannya seluruh peserta (mahasiswa) tersebut dapat mengembangkan kemampuan wirausahanya dengan harapan ketika mereka telah menyelesaikan studinya dapat mengembangkan dan menjalankan usahanya masing-masing.

Tujuan dari program ini adalah terlaksananya pelatihan dan pembimbingan pada mahasiswa dalam upaya menumbuhkembangkan budaya wirausaha mahasiswa di lingkungan IKIP PGRI Pontianak antara lain: Menumbuhkan dan meningkatkan kemampuan, minat, mahasiswa untuk menekuni dunia wirausaha, meningkatkan kreativitas berpikir mahasiswa dalam mengembangkan kemampuan 
wirausaha, membuka wawasan tentang perkembangan dunia wirausaha di Kalimantan Barat, dan memberikan motivasi kepada dosen dan mahasiswa untuk dapat berpartisipasi dalam mengembangkan dunia wirausaha di Kalimantan Barat.

Kegiatan ini memberikan manfaat pada peningkatan kemampuan, minat, motivasi, inovasi, dan kreativitas mahasiswa untuk menekuni dunia wirausaha, meningkatkan kreativitas berpikir mahasiswa dalam mengembangkan kemampuan wirausaha, membuka wawasan tentang perkembangan dunia wirausaha di Kalimantan Barat, dan Mendorong motivasi dosen dan mahasiswa untuk dapat berpartisipasi dalam mengembangkan dunia wirausaha di Kalimantan Barat.

Kegiatan ini selain memberikan manfaat langsung kepada mahasiswa juga akan berdampak positif kepada pengembangan kurikulum di lingkungan IKIP PGRI Pontianak, khususnya dalam memberikan pengetahuan dan keterampilan kepada para mahasiswa pada bidang wirausaha yang nantinya akan bermanfaat bagi perkembangan karirnya dimasa sekarang dan masa yang akan datang.

\section{METODE}

Persiapan kegiatan yang telah di rancang oleh tim pelaksana Pelatihan Kewirausahaan bagi Mahasiswa Prodi PPKn di IKIP PGRI Pontianak dimulai dari Persiapan yang sedemikian rupa tersebut menghasilkan sebuah keputusan yang dapat diterima melalui sebuah forum rapat program studi secara keseluruhan dosen yang hadir pada rapat tersebut menyatakan sepakat untuk melakukan kegiatan PKM di Kabupaten Sambas. Persiapan yang paling utama yakni persiapan perizinan mengenai lokasi kagiatan yang akan dituju dengan melayangkan surat perizinan kapada dinas terkait, maka tim izinkan untuk melakukan kegiatan. Rincian persiapan kegiatan pengabdian ini disajikan secara rinci pada Tabel 1. 
Tabel 1. Persiapan Kegiatan Pelatihan Kewirausahaan

\begin{tabular}{|c|c|c|c|c|c|c|c|}
\hline \multirow{2}{*}{ No } & \multirow{2}{*}{ Jenis Kegiatan } & \multicolumn{6}{|c|}{ Minggu Ke- } \\
\hline & & 1 & 2 & 3 & 4 & 5 & 6 \\
\hline 1 & $\begin{array}{l}\text { Persiapan: } \\
\text { a. Pengurusan perizinan } \\
\text { b. Penyampaian surat } \\
\text { pemberitahuan/undangan }\end{array}$ & $\sqrt{ }$ & $\sqrt{ }$ & & & & \\
\hline 2 & $\begin{array}{l}\text { Kegiatan: } \\
\text { a. Pembukaan acara } \\
\text { b. Penyampaian materi seminar oleh nara } \\
\text { sumber } \\
\text { c. Dialog terbuka bersama membahas } \\
\text { kewirausahaan } \\
\text { d. Latihan menyusun rencana berwirausaha } \\
\text { e. Pembahasan tugas peserta } \\
\text { f. Penilaian hasil kegiatan } \\
\text { g. Penutup }\end{array}$ & & & $\sqrt{ }$ & $\sqrt{ }$ & & \\
\hline 3 & $\begin{array}{l}\text { Pelaporan: } \\
\text { a. Penyusunan Laporan } \\
\text { b. Pengiriman Laporan }\end{array}$ & & & & & $\sqrt{ }$ & $\sqrt{ }$ \\
\hline
\end{tabular}

Berdasarkan kegiatan yang dipilih, maka metode yang digunakan untuk mensukseskan pelaksanaan kegiatan ini adalah: (1) kegiatan diskusi untuk mengenalkan konsep sekaligus rekomendasi pembicara (sosok wirausahawan muda di Kalimantan Barat yang berasal dari Kabupaten Sambas); (2) diskusi dengan narasumber untuk membenahi pengembangan muatan isi dari mata kuliah kewirausahaan; dan (3) kegiatan penugasan, yaitu menugaskan mahasiswa peserta pelatihan untuk merancang ide dan menyusun proposal pengembangan kewirausahaan.

Waktu kegiatan pelatihan kewirausahaan bagi mahasiswa prodi PPKn di IKIP PGRI Pontianak) akan dilaksanakan pada tanggal 24 Juli 2019 dengan peserta yang terdiri dari mahasiswa prodi PPKn 40 orang. Tempat kegiatan yaitu Balai Pertemuan Desa Sungai Baru Kecamatan Telok Keramat, dengan sasaran kegiatan pengabdian masyarakat ini adalah mahasiswa di prodi PPKn. Dengan konsep pengayaan pengetahuan mahasiswa terhadap dunia kerja diluar bidang kompetensi dan disiplin ilmu yang mereka tekuni, maka kegiatan yang dirancang harus sesuai dengan kebutuhannya. 


\section{HASIL DAN PEMBAHASAN}

Kegiatan Pengabdian Kepada Masyarakat (PKM) merupakan bentuk sumbangsih civitas perguruan tinggi kepada masyarakat, baik berupa masteri ataupun dalam bentuk non materi agar menjembatani kajian-kajian teoritis dengan masalah kontekstual masyarakat. Pengabdian kepada masyarakat selain merupakan kewajiban khusus dalam tri dharma perguruan tinggi juga sekaligus menjadi penyeimbang keterampilan akademis dengan keterampilan sosial warga perguruan tinggi sehingga menghasilkan generasi yang cerdas dan memiliki kepekaan untuk berpartisipasi nyata mengatasi permasalahan yang dihadapi masyarakat.

Pembangunan bidang pendidikan tentunya memiliki lingkaran yang sangat sempit menurut beberapa kalangan mahasiswa oleh karena itu PKM ini dilakukan untuk membuka cakrawala berpikir mahasiswa untuk mengenal dunia luar khususnya dalam perencanaan masa depan melalui pengenalan dunia kerja diluar kompetensi dan disiplin ilmu yang sedang mereka tekuni saat ini. Kegiatan ini diawali dengan kegiatan seminar, berupa pemberian pelatihan dengan materi kemampuan menanggung resiko, kemampuan pantang menyerah, dan pemberian motivasi. Dari kegiatan ini diharapkan pola pikir mahasiswa berubah dengan memiliki mental dan ide wirausaha. Setelah kegiatan ini para mahasiswa diperkenalkan dengan berbagai ragam dunia kewirausahaan serta memperkenalkan beberapa orang pelaku wirausaha di daerah sekitar. Hal ini sejalan dengan pendapat yang dikemukakan oleh Baum et.al (2007: 35) bahwa motivasi dalam kewirausahaan meliputi motivasi yang diarahkan untuk mencapai tujuan kewirausahan, seperti tujuan yang melibatkan pengenalan dan eksploitasi terhadap peluang bisnis. Motivasi untuk mengembangkan usaha baru diperlukan bukan hanya oleh rasa percaya diri dalam hal kemampuannya untuk berhasil, namun juga oleh kemampuannya dalam mengakses informasi mengenai peluang kewirausahaan. Dalam istilah yang lebih sempit, teori expectancy mengungkapkan bahwa informasi yang spesifik dan periodik mengenai peluang kewirausahaan dapat meningkatkan harapan individu bahwa upaya kewirausahaan akan memberikan hasil, dengan demikian akan meningkatkan motivasi. Para 
mahasiswa diperkenalkan dengan berbagai jenis usaha, seperti usaha kuliner, usaha jasa, dan usaha produk lainnya, dengan harapan setelah mereka selesai menjalani masa perkuliahan akan semakin kuat keinginan mereka untuk berwirausaha. Selanjutnya, dari seluruh peserta terlihat minat mereka berwirausaha, terlihat mahasiswa yang memang berminat untuk membuka usaha.

Sebagaimana hasil penelitian yang dilakukan oleh Resmi (2013) tentang membangun jiwa kewirausahaan melalui kegiatan pelatihan kewirausahaan di kalangan mahasiswa (sebuah model pelatihan kewirausahaan di kalangan mahasiswa). Sustainable Competitive Advantage disimpulkan bahwa program kewirausahaan yang ditawarkan dapat membangun kemampuan menanggung resiko, kemampuan pantang menyerah, dan kemampuan motivasi berwirausaha, dan hasil luaran yang diharapkan dari kegiatan tersebut menghasilkan lulusan bermental wirausaha dan mau membuka usaha.

Pelaksanaan kegiatan Pelatihan kewirausahaan bagi mahasiswa program studi pendidikan pancasila dan kewarganegaraan IKIP PGRI Pontianak terlaksana dengan baik tanpa ada hambatan yang berarti. Hal ini tergambar dari beberapa foto dokumentasi yang diperoleh pada saat pelaksanaan kegiatan berlangsung. Adapun beberapa dokumentasi yang dapat ditampilkan adalah sebagai berikut:

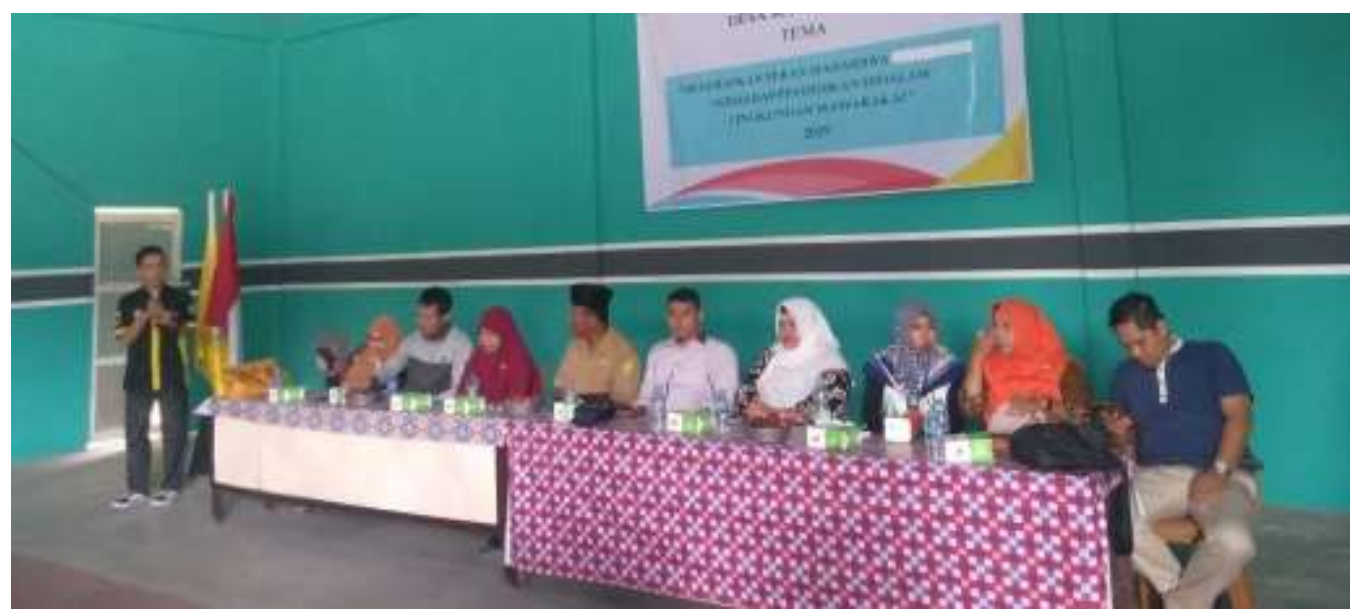

Gambar 1. Acara Pembukaan Kegiatan 


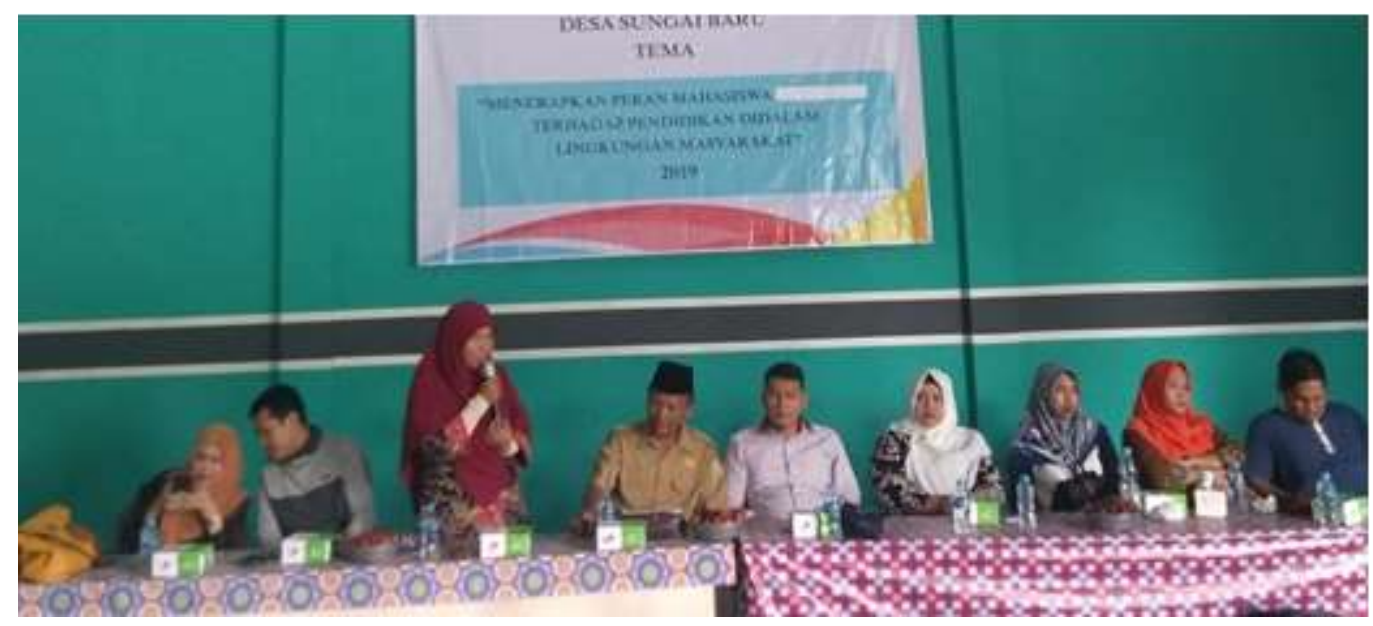

\section{Gambar 2. Ketua Prodi PPKN Memberikan kata sambutan dan sekaligus} membuka kegiatan Pelatihan Kewirausahaan Bagi Mahasiswa

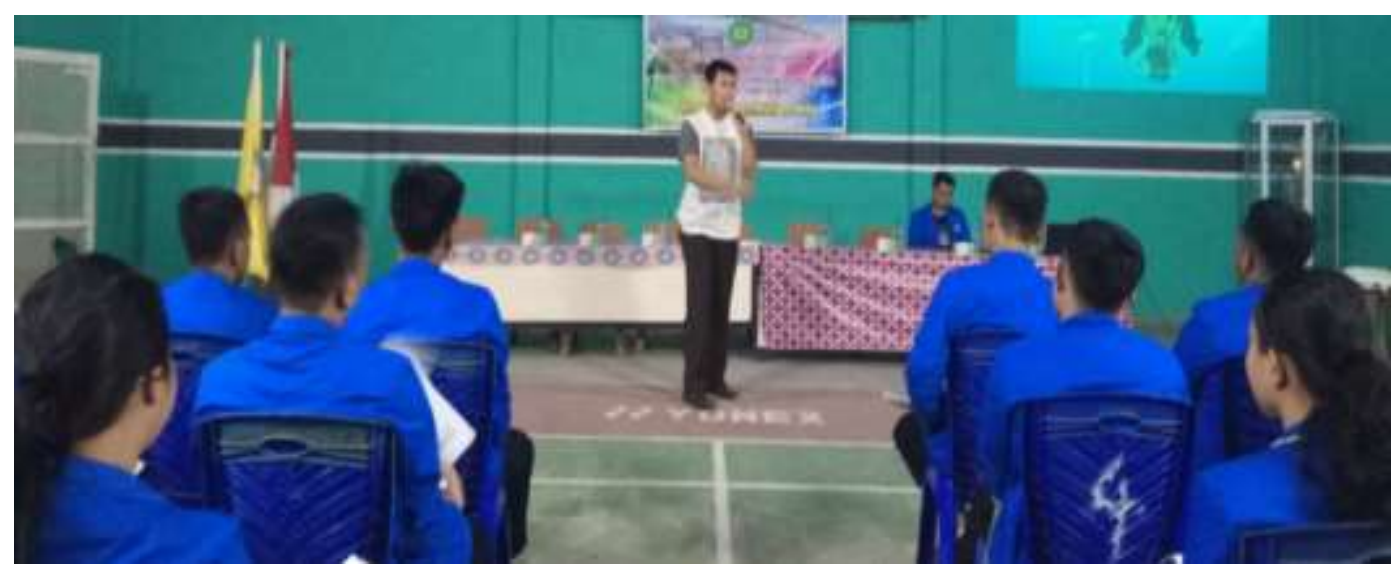

\section{Gambar 3. Penyampaian materi oleh Narasumber}

Target yang ingin dicapai adalah untuk meningkatkan minat dan motivasi wirausaha mahasiswa di lingkungan IKIP PGRl Pontianak. Sedangkan target khususnya yaitu meningkatnya kemampuan, minat, motivasi, inovasi, dan kreativitas mahasiswa untuk menekuni dunia wirausaha, hal ini diperkuat dengan hasil angket yang menunjukkan bahwa $80 \%$ atau 32 orang dari 40 orang peserta yang mengikuti kegiatan pelatihan termotivasi dan berminat untuk berwirausaha sejak di bangku kuliah hingga nanti pada saat mereka telah menyelesaikan studinya, Peningkatan kreativitas berpikir mahasiswa dalam mengembangkan kemampuan wirausaha dibuktikan dengan munculnya ide-ide kreatif berwirausaha, terbukanya wawasan tentang perkembangan dunia wirausaha di 
Kalimantan Barat dan mendorong motivasi kepada dosen untuk memberikan bimbingan serta arahan dan mahasiswa dapat berpartisipasi dalam mengembangkan dunia wirausaha di lingkungan kampus khususnya dan lingkungan Kalimantan Barat pada umumnya.

Pada penyelenggaraan kegiatan yang sama pada masa-masa mendatang perlu dilakukan kerja sama dengan berbagai pihak terkait penyelenggaraan kegiatan pelatihan tentang dunia kewirausahaan dan terus menggalakkan kegiatan-kegiatan serupa untuk memperkenalkan dunia usaha pada generasi muda sejak dini sehingga dimasa mereka telah menyelesaikan studinya kelak mereka tidak kebingungan untuk memilih bidang pekerjaan yang mereka sukai.

\section{SIMPULAN}

Pelaksanaan kegiatan Pelatihan Kewirausahaan Bagi Mahasiswa Program Studi Pendidikan Pancasila dan Kewarganegaraan IKIP PGRI Pontianak terlaksana dengan baik tanpa ada hambatan yang berarti karena tujuan dari penyelenggaraan kegiatan pelatihan ini tercapai dan secara keseluruhan upaya memberikan pengalaman pada mahasiswa yang kurang berpengalaman tentang dunia kewirausahaan, sehingga pengalaman yang mereka peroleh ini dapat menunjang kreatifitas yang tinggi dan menjadi sesuatu yang luar biasa.

\section{DAFTAR PUSTAKA}

Baum, J. R., Frese, M., \& Baron, R., A. (2007). The psychology of entrepreneurship. London: Routledge

Chandler, G., \& Hanks, S. H. (1994). Market Attractiveness, resource-based capabilities, venture strategies and venture performance. Journal of Business Venturing, 9, 331-349.

Linan. et al., (2005). Factors affecting entrepreneurial intention levels. Paper presented at 45th congress of the European regional science association, Amsterdam.

Pihie. (2009). Entrepreneurship as a career choice: An analysis of entrepreneurial self-efficacy and intention of university students. European Journal of Social Sciences. 9. 338-349.

Resmi, G. G. (2013). Membangun jiwa kewirausahaan melalui kegiatan pelatihan kewirausahaan di kalangan mahasiswa (sebuah model pelatihan kewirausahaan di kalangan mahasiswa). Sustainable Competitive Advantage (SCA), 3(1). 
Soehadi, A., W., Suhartanto, E., Winarto, V., Setiawan., M., K. (2011). Prasetiya mulya edc on entrepreneurship education. Seri kewirausahaan 1. Jakarta: Prasetiya Mulya Publishing.

Wilson, D., Cunita, A., T., Jung, W., H., Hauser, N., C., Hernandez, R., Williamson, T., KPiekarska, K., Rupp, S., Young, T., Stateva, L. (2007). Deletion of the high-affinity cAMP phosphodiesterase encoded by PDE2 affects stress responses and virulence in Candida albicans. Mol Microbiol, 65(4), 841-56

Zain, Z., M., Akram, A., M., Ghani, E., K. (2010). Entrepreneurship intention among malaysian business students. Canadian. Social_Science, 6 (3), 34-44. 